\section{Recent scientific and technical books}

\section{Biology}

VEDEL, Helge. Trees and Shrubs of the Mediterranean. (Penguin Nature Guides.) Translated from the Danish by Aubrey Rush. Edited and adapted by Hugh Synge.
Pp.127. ISBN-0-14-063010-4. (Harmondsworth, Middx.: Penguin Books, Ltd., 1978.) $£ 1.95$

VOGEL, Henry J. (edited by). Nucleic Acid-Protein Recognition. (P \& S Biomedical Science Symposia Series.) Pp.xxvi + 587. ISBN-0-12-722560-9. (New York
and London Academic Press, a Subsidiary of Harcourt Brace Jovanovich, Publishers, 1977.) $n$ p. (No pub. date.)

VRBOVA, Gerta, GORDON, Tessa, and JONES, Rosemary. Nerve-Muscle Interaction. Pp.xiii + 233. ISBN-0-412-15720-9. (London: Chapman and Hall, 1978. New York.) $£ 15$.

\section{Applied Biology}

AGRANOFF, B. W., and APRISON, M. H. (edited by). Advances in Neurochemistry, Vol. 3. Pp.xiii +304.
Plenum Press, 1978.) $\$ 20.47$.

AHMAD, F., SCHULTZ, J., RUSSELL, T. R., and WERNER, R. (edited by).

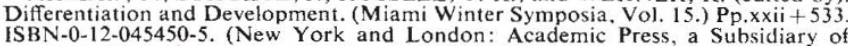
ISBN-0-12-045450-5. (New York and London: Academic Pres
Harcourt Brace Jovanovich, Publishers, 1978.) \$29.50; $£ 19.15$.

Harcourt Brace Jovanovich, Publishers, 1978.) $\$ 29.50 ; £ 19.15$.
ALABASTER, John S. (edited by). Recreational Freshwater Fisheries: Their Conservation, Management and Development. (Proceedings of a Conference of the Water Research Centre, held at Keble College, Oxford, 12-15 December
1977.) Pp.xvii +312 . (Medmenham, Marlow: Water Research Centre, Medmenham 1977.) Pp.xvii +312 . (Medmenham,
Laborator, PO Box 16, 1978.) £10.

ARBER, W. et al. (edited by). Current Topics in Microbiology and Immunology, Vol. 82. Pp.iii + 138. ISBN-3-540-08981-0. (Berlin and New York: Springer-Verlag, 1978.) DM. $65 ; \$ 32.50$

ATASSI, M. Z., and STAVITSKY, A. B. (edited by). Immunobiology of Proteins and Peptides-1. (Advances in Experimental Medicine and Biology, Vol. 98.) Pp.x +513 . ISBN-0-306-32698-1. (New York and London: Plenum
Press, 1978.) \$28.35. BENIRSCHKE, K., GARNER, F. M., and JONES, T. C. (edited by). Pathology of Laboratory Animals. Volumes 1 and 2. Pp.lxiv + 2225. ISBN-3-5

BEUTLER, Ernest. Hemolytic Anemia in Disorders of Red Cell Metabolism (Topics in Hematology.) Pp.xiii 1.266. ISBN-0-306-31112-7. (New York and London: Plenum Medical Book Company, 1978.) \$14.80.

BEYER, Karl H. Discovery, Development and Delivery of New Drugs. (Monographs in Pharmacology and Physiology.) Pp.238. ISBN-0-89335-052-4. (New York and London: SP Medical and Scientific Books, a Division of Spectrum Publications Inc., 1978.) £14

BOOTH, D. A. (edited by). Hunger Models: Computable Theory of Feeding Control. Pp.xviii +478. ISBN-0-12-115950-7. (London and New York: Academic Press, a Subsidiary of Harcourt Brace Jovanovich, Publishers, 1978.) £18.50. BROOK, C. G. D. Practical Paediatric Endocrinology. Pp.142, ISBN-0-12.
136050-4. (London: Academic Press; New York: Grune and Stratton, Inc., 1978.) 136050-4. ( $£$ L. 6 . $\$ 3$.

BROUN, Georges B., MANECKE, Georg, and WINGARD, Jr., Lemuel (edited by). Encyme Engineering, Vol. 4. Pp.xx + 492. ISBN-0-306-35282-6 (v.2). (New York and London: Plenum Press, 1978.) np. (No pub. date.)

CANAL. N., and POZZA, G. (edited by). Peripheral Neuropathies. (Proceedings of the International Symposium held in Milan, Italy, on June 26-28, 1978. dam, New York and Oxford: Elsevier/North-Holland Biomedical Press. 1978.)

CAUGHEY, Winslow S. (edited by). Biochemical and Clinical Aspects of Hemoglobin Abnormalities. (Proceedings of a Symposium held on the Pingrec Park Campus, Colorado State University, October 2-7, 1977.) Pp.xx +725. Harcourt Brace Jovanovich. Publishers, 1978.) \$33.50; £21.75.

CHANDLER, A. Bleakley, EURENNUS, Karl, McMILLAN, Gardner C NELSON, Curtis B., SCHWATTZ, Colin J., and WESSLER, Stanford (edited by). The Thrombotic Process in Atherogenesis. (Advances in Experimental Medicina and Biology, Vol. 104.) Pp.xvit

Plenum Press, 1978.) \$29.92.
CLINICAL ONCOLOGY: a Manual for Students and Doctors. Edited under the auspices of the International Union Against Cancer. Pp.xv+304. ISBN-3-54008868-7. (Berlin and New York: Springer-Verlag, 1978.) DM.29; \$14.50. COAKER, T. H. (edited by). Applied Biology, Vol. 3. Pp.x +418. ISBN-0-12040903-8. (London and New York: Academic Press, a Subsidiary of Harcourt Brace Jovanovich, Publishers, 1978.) £16.80

COTTRAL, George E. (edited by). Manual of Standardized Methods for Veterinary Microbiology. Pp.731. ISBN-0-8014-1119-X. (Ithaca and London:
Comstock Publishing Associated, a Division of Cornell University Press, 1978.) Comstock

CURTIS, Adam (edited by). Cell-Cell Recognition. (Symposia of the Society for Experimental Biology, No. 32.) Pp.viii +478. ISBN-0-521-22020-3. (Cambridge,
London and New York: Cambridge University Press, 1978. Published for the London and New York: Cambridge

DAY, H. James, MOLONY, Basil A., NISHIZAWA, Edward E., and RYNBRANDT, Ronald H. (edited by). Thrombosis: Animal and Clinical Models. (Advances in Experimental Medicine and Biology, Vol. 102.) Pp.ix +337 EBRAHIM, G. J. A Handbook of Tropica PPaediatrics. (Macmillan Tropical Community Health Manuals.) Pp.vii + 87. ISBN-0-333-24039-1. (London and Basingstoke: The Macmillan Press, Ltd., 1978.) Hardcover $£ 4.95$; Paperback $£ 1$ 1.10. EBRAHIM, G. J. Child Care in the Tropics. (Macmillan Tropical Community
Health Manuals.) The Macmillan Press, Ltd., 1978.) Hardcover £5.95; Paperback $£ 1.20$.

EBRAHIM, G. J. Practical Mother and Child Health in Developing Countries, (Macmillan Tropical Community Health Manuals.) Pp.vi+130. ISBN-0-33324111-8. (London and B

£5.95; Paperback £1.30.
FINNEY, David J. Statistical Method in Biological Assay. Third edition. Pp.x +508. ISBN-0-85264-252-0. (London and High Wycombe: Charles Griffin and Co.. Ltd., 1978.) £19 net.

FLAMM, W. Gary, and MEHLMAN, Myron A. (edited by). Advances in Modern Toxicology. Vol. 5: Mutagenesis. Pp.xii +401. ISBN-0-470-99393-6.
(Washington, DC. and London: Hemisphere Publishing Cornoration, 1978. Distributed solely by Halsted Press, a Division of John Wiley and Sons, Inc.. New York and Chichester.) $£ 17.50$

New York and Chichester.) 17.50 . FLOREY, Klaus (edited by). Analytical Profiles of Drug Substances, Vol. 7.
Pp.ix +504. ISBN-0-12-260807-0 (v.7). (New York and London: Academic Press: Pp.ix +504 . ISBN-0-12-260807-0 (v.7). (New York and London: Academic
a Subsidiary of Harcourt Brace Jovanovich, Publishers, 1978.) $\$ 24 ; £ 15.60$.

FRAENKEL-CONRAT, Heinz, and WAGNER, Robert R. (edited by). Comprehensive Virology. Vol. 12: Newly Characterized Protist and Invertebrate
Viruses. Pp.xv + 344. ISBN-0-306-35152-8. (New York and London: Plenum Press, 1978.) $\$ 18.58$
FRIEDMAN, Mendel (edited by). Nutritional Improvement of Food and Feed Proteins. (Advances in Experimental Medicine and Biology, Vol. 105.)
Pp.xiii + 882. isBN-0-306-40026-X. (New York and London: Plenum Press, 1978.) np.

GALLI, C. L., PAOLETTI, R., and VETTORAZZI, G. (edited by). Chemical Toxicology of Food. (Proceedings of the International Symposium, Milan, June 8-10, 1978.) (Developments in Toxicology and Environmental Science, Vol. 3.) North-Holland Biomedical Press, 1978.) Dfl.108; \$48

GOLDSTEIN, Jerome (edited by). The Least is Best Pesticide Strategy: a Guide (Emmaus, PA.: The JG Press, 1978.) \$6.95

GROSSMAN, Morton, SPERANZA, V., BASSO, N., and LEZOCHE, E. (edited by). Gastrointestinal Hormones and Pathology of the Digestive System. (Advances in Experimental Medicine and Biology, Vol. 106.) Pp.x +326 . ISB-0-306-40023-5. (New York and London: Plenum Press, 1978.) \$22.05.
GUELEN, Pieter J. M., and van der KLEIJN, Eppo. Rational Anti-Epileptic Drug Therapy. Pp.ix +182 . ISBN-0-444-80077-8. (Amsterdam, New York and Oxford: Elsevier/North-Holland Biomedical Press, 1978.) Df.65.

HEINDEL, Ned D., BURNS. H. Donald, HONDA, Takashi, and BRADY, Luther W. (edited by). The Chemistry of Radiopharmaceuticals. (Cancer Manage-
ment '78.) Pp $x+294$. ISBN-0-89352-019-5. (New York and Paris: Masson Publishing ment 78.) Pp.x + 294. ISBN-0-89352-019-5. (New York and Paris:

HILLIS, W. E., and BROWN, A. G. (edited by). Eucalypis for Wood Production. Pp.xii + 434. ISBN-0-643-02245-7. (East Melbourne, Victoria: Commonwealth Scientific and Industrial Research Organization, Editorial and Publications Service, 1978.) \$A28.

HODGSON, J. M. Soil Sampling and Soil Description. (Monographs on Soil Survey.) Pp.viii +241. ISBN-0-19-8545 II-8

xford University $\mathrm{P}$

HUMPHREYS, L. R. Tropical Pastures and Fodder Crops. (Intermediate Gropical Agriculture Series

IVERSEN, O. H., DONALD, K. J., and de VRIES, M. J. (edited by). Basic Text in General Pathology. (Integrated Pathology Audiovisual Learning System.) tetsforlaget; London Global Book Resources, Ltd., 1978.) £7.85. Second edition. KLEIN, George, and WEINHOUSE. Sidney (edited by). Advances in Cancer
Research, Vol, 28. Pp. $1-409$. ISBN-0-12-006628-9. (New York and London: Research, Vol. 28. Pp.x 1-409. ISBN-0-12-006628-9. (New York and London: Academic Press, a Subsidiary of Harcourt Brace Jovanovich, Publishers. 1978. $\$ 31 ; £ 20.15$.
KOBAYASH, Toshiji. Clinical Ultrasound of the Breast. Pp.xv +174 . ISBN-0. 306-31109-7. (New York and London: Plenum Medical Book Company, 1978.)

KUMAR, Sudhir, and RATHI, Manohar (edited by). Perinatal Medicine: Clinical and Biochemical Aspects of the Evaluation, Diagnosis and Management of
the Fetus and Newborn. Pp.xi+266. ISBN-0-08-02 1517-3. (Oxford and New York: the Fetus and Newborn. Pp.x

Pergamon Press, 1978.) $£ 15$. LANGHANS, Robert W. (edited by). A Growth Chamber Manual: Environ-
mental Control for Plants. Pp.222. ISBN-0-8014-1169-6. (Ithaca and London: mental Control for Plants. Pp.222. ISBN-0-8014-1169-6. (Ithaca and London:
Comstock Publishing Associates, a Division of Cornell University Press, 1978.) $£ 12.25$.

LIPKIN, Martin, and GOOD, Robert A. (edited by). Gastrointestinal Tract Cancer. (Aloan-Kettering Institute Cancer Series.) Pp.xvii + 602. ISBN-0-306-
31098-8. (New York and London: Plenum Medical Book Company, 1978.) \$23.62. 31098-8. (New York and London: Plenum Medical Book Company, LITMAN, Gary W., and GOOD, Robert A. (edited by). Immunoglobulins. and London: Plenum Medical Book Company, 1978.) \$18.58.

MARGEN, Sheldon, and OGAR, Richard A. (edited by). Progress in Human Nutrition, Vol. 2. Pp.xiii +313 . ISBN-

Publishing Company, Inc. The Children of Santa Maria Cauqué: a Prospective Field Study of Health and Growth. Pp.xvii - 395. ISBN-0-262-13135-8. (Cambridge. Mass. and London: The MIT Press, 1978.) f14.

MUIR, C. S., and WAGNER, G. In collaboration with DEMARET, E., NAGYTIBORCZ, A., and SCHLAEFER, K. Directory of On-Going Research in Cancer 832-1126-X. (Lyon: Internationat Agency for Research on Cancer, 1978. Distributed by WHO. Geneva; and HMSO, London.) Sw.fr.30.

NANDY. Kalidas (edited by). Senile Dementia: a Biomedical Approach, (Proceedings of the Conference held in St. Louis, Missouri, USA, on March 22-23. 1978.) (Developments in Neuroscience, Vol. 3.) Pp.xxiii + 303. ISBN-0-444-00271-5(New York and Amsterdam: Elsevier/North-Holland Biomedical Press, 1978.) \$28, Pp.xii + 288. ISBN-0-262-14029-2. (Cambridge, Mass. and London: The MIT Press, 1978.) £15.75.

NOTMAN, Malkah T., and NADELSON, Carol C. (edited by). The Woman Patient: Medical and Psychological Interfaces. Vol. 1: Sexual and Reproductive Aspects of Women's Health Care. (Women in Context: Development and Stresses.)
Pp.xii 363. ISBN-0-306-31151-8. (New York and London: Plenum Press, 1978.) $\$ 12.28$.

OSBORNE, D. R., and VOOGT, P. The Analysis of Nutrients in Foods. (Food Science and Technology: a Series of Monographs.) Pp.vii +251 . ISBN-0-12Jovanovich, Publishers, 1978.) £10.50;\$21.75

PETTIT, George R., and CRAGG, Gordon M. Biosynthetic Products for Cancer Chemotherapy, Vol. 2. Pp.ix +150 . ISBN-0-306-37688-1 (v. 2). (New York and London: Plenum Press, 1978.) \$18.58.

RICCI, M., FAUCI, A. S., ARCANGELI, P., and TORZUOLI, P. (edited by). Developments in Clinical Immunology. Pp.ix +266. ISBN-0-12-587180-5. (New York and London: Academi
1978 .) $£ 12 ; \$ 24.75$.

SILBER, Robert, LOBUE, Joseph, and GORDON, Albert S. (edited by). The

Year in Hematology, 1978. Pp.xvii + 517. ISBN-0-306-32402-4. (New York and
London: Plenum Medical Book Company, 1978.) \$18.58. STRICKLAND, Stephen P. Research and the Heaith of Americans: Improving
the Policy Process. Pp.xxiii + 162. ISBN-0-669-02165-2. (Lexington, Mass., Toronto, the Policy Process. Pp.xxiii +162 . ISBN-0-669-021
and Farnborough: Lexington Books, 1978.) $£ 12$.

and Farnborough: Lexington Books, 1978.) $£ 12$.
TWOMEY, J. J., and GOOD, Robert A. (edited by). The Immunopathology of Lymphoreticular Neoplasms. (Comprehensive Immunology, Vol. 4.) Pp.xx +763.
ISBN-0-306-33104-7. (New York and London: Plenum Medical Book Company, 1978.) $\$ 28.35$.

TAYLOR, Angela E. R., and BAKER, John R. (edited by). Methods of Cultivating Parasites in Vitro. Pp. $\mathrm{x}+301$. ISBN-0-12-685550-1. (London and New York: Academic
$£ 14.50$.

URAGUCHI, Kenji, and YAMAZAKI, Mikio (edited by). Toxicology: Bio(New York and London: Halsted Press, a Division of John Wiley and Sons; Tokyo: New York and London: Halsted Press, a Division of John Wiley and Sons; Toky.
Kodansha, Ltd., 1978.) 19.50 . Hormone Relations and the Physiopathology of Pregnancy-Hormone Investigations:
Hypothalamic/Hypophyseal Relations. Pp.viii + 272. ISBN-0-89352-017-9. (New York and Paris: Masson Publishing USA, Inc.; Tunbridge Wells: Abacus Press, Ltd., 1978.) £26.35.

VSNDERPLANK, J. E. Genetic and Molecular Basis of Plant Pathogenesis. (Advanced Series in Agricultural Sciences, 6.) Pp.xi +167.
(Berlin and New York: Springer-Verlag, 1978.) DM $48 ; \$ 24$. 